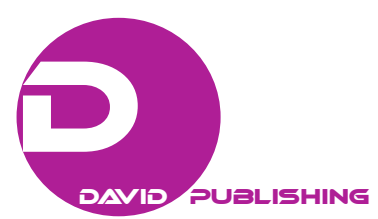

\title{
Research on Knowledge Management in Global Scenarios
}

\author{
Edmir Kuazaqui \\ Escola Superior de Propaganda e Marketing, São Paulo, Brazil \\ Teresinha Covas Lisboa \\ Florida Christian University, Orlando, USA \\ Universidade Paulista, São Paulo, Brazil
}

\begin{abstract}
The aim of this article is to demonstrate how the opening of economies to the international market has intensified the need for companies to prepare themselves for the challenges and opportunities of globalization, as well as the knowledge of theoretical, technical, and cultural strategies that contribute economically and socially to the population. In this way, this phenomenon demonstrates a dynamic way of doing business, which should be the object of extensive study by the company as well as the academic community, thus enabling reflection and the correct management of the globalization process as well as professionals with specific practices and national and international experiences; obtaining this knowledge stems from technical and behavioral skills as well as skills presented by the individual. In the latter case, the competence models arise to integrate people in organizational models. We applied qualitative research, with consultant testimonials who work in international fields, for the development of this article. We concluded that management knowledge as well as intellectual capital management becomes the greatest challenge for everyone seeking sustainability and success in international business.
\end{abstract}

Keywords: knowledge management, scenarios, global, internationalization, competences, capital intellect

\section{Introduction}

Internationalizing careers is closely linked to the professional training of the individual. One can see that it has become an instrument for governmental bodies on the evaluation of higher education institutions, in addition to being an encouragement for young people who are starting their careers.

Hengemuhle (2014, p. 35) affirmed "in the development of competent persons and entrepreneurs, one easily deduces that we cannot educate them only through the ability of repeating the legacy that has been passed on to them". Therefore, people need to be attentive to new situations or with the expectation of turning away from routines.

The growth of the production market for goods and services crossed borders and, with this, the universities were forced to diversify graduate and post-graduate courses, because it is the current requirement of individuals and entrepreneurs.

Edmir Kuazaqui, Ph.D., M.S. in Business Administration, professor at Escola Superior de Propaganda e Marketing (ESPM), São Paulo, Brazil.

Teresinha Covas Lisboa, Ph.D. in Administration, Florida Christian University, Orlando, USA; Ph.D. in Administration, M.S. in Administration, professor at Universidade Paulista (UNIP), São Paulo, Brazil.

Correspondence concerning this article should be addressed to Edmir Kuazaqui, Alencar de Araripe Street 1517, Ipiranga, São Paulo 04253-000, Brasil. 
Knowledge management arises, then, as a linking tool between the market and the educational institutions in molding a professional that will be fit for a new scenario and aware of his/her technical and behavioral skills.

These characteristics have a dynamic based on technological innovation and the field of knowledge development. Scientific breakthrough allows technology to change social behavior, especially in people, because it is closely connected with art, creation, and intellectual development.

The new business environment is composed of numerous variables that imply for more diversified training. We included, in this study, the internationalization that involves new concepts for negotiation and that requires a knowledge of these dynamic markets.

Knowledge management is currently one of the most studied topics in terms of internationalization, mainly by leveraging the competitive advantage. According to Ribeiro (2012, p. 20), "in today's world, knowledge has become the raw material of competitive advantage".

Other aspects that interfere with knowledge, as mentioned by Takeuchi and Nonaka (2009):

- Socialization: Sharing and hands on knowledge through direct experience. This happens between one individual and another.

- Outsourcing: Articulation of tactical knowledge obtained through dialogue and reflection. This occurs when an individual multiplies knowledge for the group.

- Combination: Systematization and application of knowledge with the explanation of the group to the organization.

- Internalization: Learning and obtaining new knowledge transmitted from the organization to the individual.

Therefore, we see that knowledge management involves interaction between people and demonstrates that an organization does not create knowledge by itself however; it does so with the people.

Educational institutions need to walk aligned with this innovation, by establishing projects that allow their students to study and research the generation of knowledge at national and international universities.

\section{Theoretical Framework}

\section{Concept of Competencies}

The concept of competencies is presented by Dutra (2004, p. 28) who gave basis to the discussion about knowledge management and conceptualized it as a "...set of knowledge, skills, and attitudes necessary for the person to develop his/her roles and responsibilities".

Queiroz (2008, p. 21) defined it as "a set of correlated skills, knowledge, and attitudes where action adds value to the individual and the organization, in what we call delivery".

Organizations are contained within a systemic approach, where one finds support on the theory that "sees the organization as a complex meeting of parts oriented towards a given order, continuously relating itself with an external environment” (Meireles \& Paixão, 2003, p. 169). The author complemented this with the concept that "the organization is seen as a set of elements, dynamically linked in search of a purpose, operating on data, energy and matter” (Meireles \& Paixão, 2003, p. 169). It is the holistic view of the health services.

Morin (2008), as well, using Pascal's thoughts, stated that the understanding of all is possible only through the knowledge of the parts and one can only know the parts from the moment one knows everything. Companies, for example, work in this way because they have units that do not act in isolation.

Complemented with the experience of Queiroz (2008), it discussed technical and behavioral competence, focusing on knowledge, skills, and attitudes (know, know how to do, and want to do). 
Chiavenato (2009, p. 312) conceptualized skills as the characteristics that are needed for obtaining and sustaining a competitive advantage.

The focus of the author is on organizational competence, aiming at the strategy and is related to the articulations for obtaining resources. The study is divided into two phases: the organization on one side and people on the other. However, both walk parallel to each other when aiming for the proposed objectives.

Queiroz (2008) quoted variables that are evident in a competent individual, as shown in Table 1.

Table 1

Variables of a Competent Individual

\begin{tabular}{ll}
\hline Knowledge & $\begin{array}{l}\text { KNOW. Encompasses the knowledge learned in college courses, by reading, at work and in the school } \\
\text { of life. Example: knowing the different swimming strokes. }\end{array}$ \\
\hline Ability & $\begin{array}{l}\text { KNOW HOW TO DO. It is the practical dimension that we developed as we employ the acquired } \\
\text { knowledge. Example: exercise in the pool, swimming, and training the skill of swimming. }\end{array}$ \\
\hline Attitudes & $\begin{array}{l}\text { WANT TO DO. It is the personal predisposition to do an action. It is what leads us to put into practice } \\
\text { our knowledge and skills. Example: discipline and persistence in learning and practicing swimming. }\end{array}$ \\
\hline Delivery & DO. Is to run effectively. Put into practice. Example: swim effectively. \\
\hline
\end{tabular}

Source: Queiroz (2008, p. 22).

The demonstration of these variables is evidenced through the description of positions and functions and is evaluated throughout function development. The managers draw up the corrective actions in order to align behavior with the variables mentioned.

In Table 2, we see the distinctions between technical competence and behavior. An individual can demonstrate great technical competence, however on the behavioral phase demonstrate certain misalignment that needs to be evaluated.

Table 2

Distinctions

\begin{tabular}{lll}
\hline Knowledge & Know & Technical competences \\
\hline Ability & Know how to do & Behavioral competence \\
\hline Attitude & Want to do & \\
\hline
\end{tabular}

Source: Queiroz (2008, p. 22).

In service companies, for example, we find knowledge, which is retrieved from educational institutions and empowering the individual to exercise his/her technical activity (know how to do); and the want to do, which is his/her behavioral competence, the moment of dedication to his/her activities, and that takes the professional on to humanization.

\section{Models}

The study of skills includes two models: individual and organizational. According to Fernandes (2013, p. 19), organizational competence is "a set of articulated resources that generate value for the organization and that can be transferred to other areas, products, or services of the organization and impact organizational performance in a key factor of success”.

On the other hand, individual competence is "a set of knowledge, skills, attitudes, and values that an individual mobilizes and applies, in a repeated manner, within a professional context, adding value to the organization and him/herself” (Fernandes, 2013, p. 48). 
Table 3

Skills Definition per Axis

\begin{tabular}{ll}
\hline Organizational skills & Individual skills \\
\hline Cost & Cost orientation and qualities \\
\hline Quality & Resource and deadline management \\
\hline Productive process & Teamwork \\
\hline Distribution & Planning \\
\hline Market monitoring & Multi-functionality \\
\hline Strategic partnership & Interpersonal relationships \\
\hline Innovation of products and processes & Capability for innovation \\
\hline Quality & Effective communication \\
\hline Technological monitoring & Internal and external coordination \\
\hline Image & Absorption and transfer of knowledge \\
\hline Strategic technological partnerships & Leadership and teamwork \\
\hline Meet the needs of expectations & Troubleshooting \\
\hline Decisions based on facts and data & Use of data and technical information \\
\hline $\begin{array}{l}\text { Source: Framework developed and adapted by the authors based on the reflections made by A. C. C. Fleury and M. T. L. Fleury } \\
\text { (2000). }\end{array}$
\end{tabular}

Organizational and individual skills need, for their existence and survival, skills, and organizational knowledge and are closely linked with the strategic management of the organization, being part of the elements that make up the competitive success of each sector. For Fernandes (2013), they are "enlightenment, skills, attitudes, and values”.

The individual may be hired for his/her skills and competence; however, the company needs to offer space for that person's performance, because demotivation at work can prevent the two variables, resulting in low-quality service.

In Table 3, we see a differentiation of competences, although it is important to remember that both go hand in hand.

Thus, we are able to assess the team by checking if the competences imposed by the organization are being met in their entirety. If not, corrective actions are established for improving service quality. The selfsame customer points out the intercurrences of this service.

An example of this evaluation is the service of a hotel reception, as it is the first contact that the guest establishes with the institution. The reception personnel must be well-trained, "like people", demonstrate cordiality, respect, ethics, politeness, and empathy. The information must be reliable and true and show efficient solutions for any possible complications. In this case, we glimpse the technical and behavioral skills.

\section{Evaluation}

The assessment consists of the following items, as quoted by Dutra (2004):

- Analysis of the persons stemming from their individuality: When the person cannot deliver what is expected of him/her;

- Analysis of individual shortcomings: When one can detect the reason for not fulfilling the job;

- Analysis of the effectiveness of development actions: When it is possible to measure the complicity between the action and the plan of action; 
- Suitability of developing actions: On the same way that one analyzes people while respecting their individuality and uniqueness, it is important to think about their development.

The role of the manager, as an evaluator, is to be an integrator, as well. In this way, the appreciation and professional development of the person encourages both personal and professional growth.

Limongi-França (2005) showed us a study carried out by some companies, such as American Express, Alcoa, AT\&T, General Electric, Unilever, and others, in which two types of skills are identified: practices and attributes.

One refers to practices, as the activities that people perform in their work environment, aiming for results. Attributes are knowledge, skills, and other features that people should have to carry out their work.

Therefore, the academic vision offers a theory, knowledge and the need to seek new horizons. Professional vision, know how to do, experience, ethics, and the knowledge that the individual is able to internationalize his/her career, is obtained through career development.

\section{The Internationalization of an Enterprise}

With the success of the activities of the companies in the domestic market, it is possible for business expansion from the internationalization processes. In general, enterprises reach economic growth using local and regional domestic opportunities, concentrating their strategic positioning in such a way as to differentiate themselves and achieve a required competitive advantage. After the exhaustion of domestic market opportunities, the companies can opt for competitive repositioning, migration to other business segments and/or seek their economic development through the extension of their overseas activities, once they are properly enabled and have conditions to assume all the responsibilities of the steps in the process of internationalization.

An extremely important diagnostic tool is the SWOT analysis, which seeks to identify the strengths and weaknesses related to the internal environment of a company, as well as the opportunities and threats regarding its external environment. However, because it is an analysis with various qualitative variables, mainly related to human capital and knowledge, the important points are not always covered, causing a bias in the interpretation, analysis, and execution of the strategy. One of the main points is based on pillars relating to marketing, finance, and knowledge.

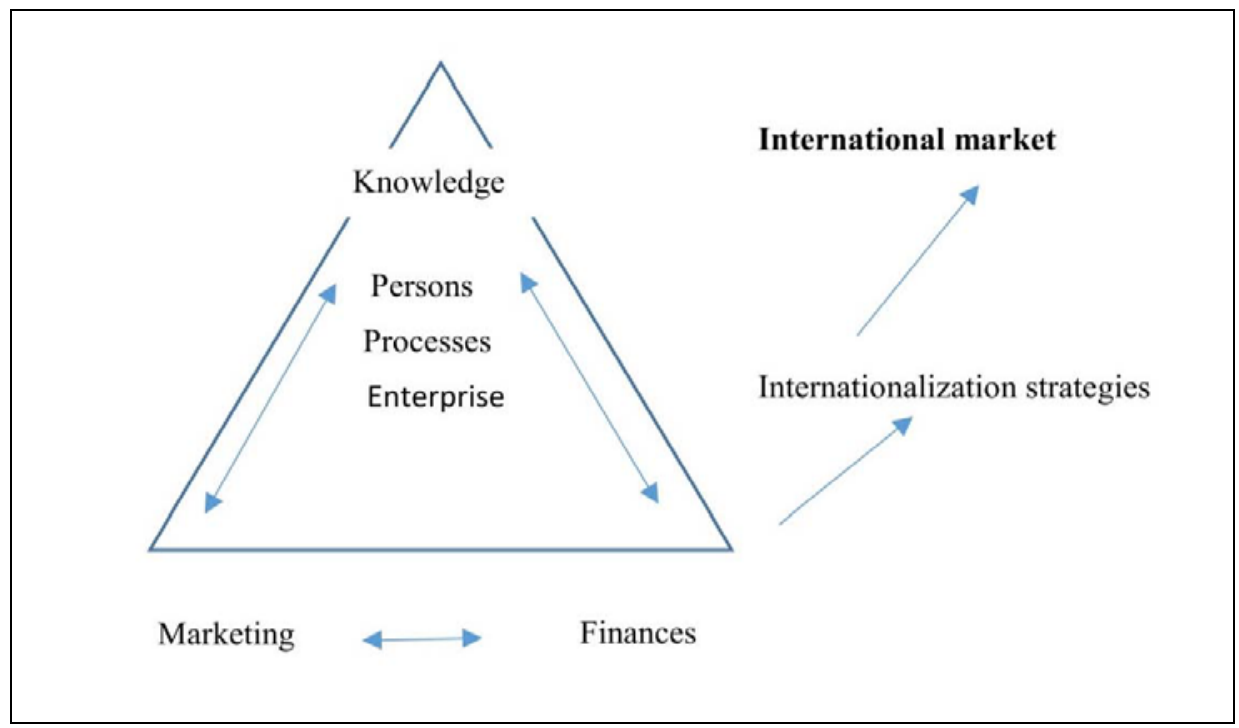

Figure 1. Basic pillars for internationalization. Source: Authors. 


\section{Management of Knowledge and Intellect Capital in Internationalization Processes}

It is agreed that every company and its respective internal collaborators add value and quality to their professional profiles, mainly arising from the accumulation of knowledge gained from unique experiences afforded by challenges that the professionals are submitted to in the internationalization processes.

In addition to technical and market knowledge, added to this is a deeper study of planning and management tools, consolidated within human and professional skills. Therefore, the way to build knowledge management and intellectual capital should be related to a career plan, highlighting essential management skills.

Capital intelligence, according to Pfeil (2003, p. 23), consists of the differences between market values and the accounting value of a company, turning towards goodwill, representing in this way the value of intangible assets, predominately human, and client, in the possession of a company and that present an economic value. According to Alavi and Ledner (2001), knowledge management is a set of processes and technologies with the objective of motivating the creation, development, transfer, and application of knowledge in the organizations and their respective intelligence capital.

Knowledge and knowledge management are complex and multifaceted concepts. In this way, the development and implementation of a knowledge management, which would be efficient, requires a rich foundation.

A major challenge lies in the fact that the company must have a systematic behavior for learning to learn, and systematically registering the experiences acquired, regardless of the staff that produced them. With the growing need for obtaining results combined with the turnover, it is common for companies to lose control of their experiences, whether they are positive or negative, as well as the results that have been acquired. Experiences are not tangible goods that can simply be photographed and measured physically; experiences are individual, subjective, and intangible knowledge, which must be properly studied, analyzed, monitored, and used in decision-making and strategic processes.

Case management is a systematic way, of a company, for registering activities, particularities, and outcomes of each stage, until their accomplishment. The intention is not to bureaucratize or stifle the steps of an activity, but to look for ways of making, what the company actually does, each time more manageable. One of the contributions is the better use of resources and the achievement of better productivity. This term is generally related to the quantity produced in relation to the resources of raw materials and supplies, for example. However, the greatest gain lies in human productivity, mainly resulting from problem-solving.

\section{Methodology}

According to a survey conducted by the authors, using the focus group method, nine professionals, listed by order of citation, from midsize businesses, with at least five years' experience, as main indicators of this management:

- Academic training and other forms of obtaining specific technical knowledge within a career plan.

- How the internal employees obtained technical updating and deepening, be it through the company, as well as proactively.

- Time of experience at the company, including indication of any job rotation (processing in other areas of the company).

- Results earned effectively from "business” goals and objectives. 
- Ability for interpersonal communication, logical reasoning, and policy articulation.

- Ability and ease for working in teams.

- Cultural education, which provides for discussion and argumentation when facing different scenarios and multicultural environments.

- Development of knowledge, skills, attitudes, abilities, and competencies deemed as necessary, as well as those considered emergent.

The sample was chosen through criterion accessibility, that according to Vergara (2014, p. 47), is one that, "far from any statistical procedure, selects elements for the ease of their accessibility". Stemming from the items listed, the interviewees concluded a need for long-term systemic thinking and strategic planning, considering identification, knowledge development and monitoring, abilities, attitudes, and necessary business competences.

Gramigna (2007, p. 50) stated that competencies can be observed routinely in three other indicators:

- Knowledge (knowing), which is directly related to academic training, to the complements provided by other sources of education and culture, as well as ones self-development and learning within the organization.

- Abilities (know how to do), which is in the application of instrumental knowledge in an organized and planned manner. In other words, put into practice, with due quality, theoretical knowledge, at times subjective, in actions that meet, in a powerful, efficient, and effective way, the different demands according to the expected results.

- Attitudes (willingness), associated with behavior, human principles and values that positively direct the actions toward the business`s goals and objectives.

J. L. Daniels and N. C. Daniels (1996, p. 136) contributed to the discussion on management skills:

Companies bring employees from many areas of the company to go through the experience of working together on inter-geographic and cross-functional issues. While developing confidence, employees are able to create networks used for conducting business and they gain experience while working on process issues. They also develop awareness in relation to other employees and their capabilities that extends and accelerates the communication process.

According to the results of the research, the ability for relocation, the adaptability to new realities and situations, and emotional intelligence are relevant to those participating as expatriates in the processes of internationalization. In addition, Lowman (2004, p. 269) stated: "Read the meaning of interpersonal communications and empathize with the variety of human experiences is second nature to some individuals".

The research also pointed out that, in addition to tracking and monitoring through indicators, companies must establish, within a career plan that is transparent and known by all, the means for reciprocating and rewarding the efforts of an individual and a group for their organizational talents. This career path is derived from the effective and fair performance evaluation. Cavusgil, Knight, and Risenberger (2010, p. 420) stated:

In the course of performance evaluation, the managers compare the expected results with the actual performance. Multinationals normally elaborate diagnostic procedures to assess the performance of individual employees making sure that all problems are attributable to inadequate levels of qualification, as well as providing the training and resources needed, and laying off employees who fail to achieve the set goals.

According to the interviewees, this complexity highlights the importance of strategic planning and monitoring of the implementation of macro strategies and micro strategic plans, especially considering that the company must have the resilience needed to identify in advance and overcome barriers and obstacles relating to international business. 
All this movement gives rise to a number of benefits. According to Dicken (2010, p. 587), "The diversity of existing economies in the world offers many possibilities for generating satisfactory and fair communities, in a more generic manner, to reconsider globalization as a transformable social process and not a force of nature”.

Analogically to the author's claim concerning business migration, the possibility of expanding to international markets implies in benefits for everyone, through the option for new products and services, but primarily for local and regional development brought on by the need for cultural and technical improvement and new experiences that they have had. Many of the business experiences are part of the historical and strategic framework of the organizations, having been disclosed through journalistic communication or case studies directed at academic circles, which somewhat reduces the prospects for a deeper discussion on the research and results of the management of knowledge and intellectual capital in internationalization processes.

\section{Conclusions}

Knowledge management involves aspects that require people to be able to take on national and international challenges. As regards to the global scenario, one expects a complete education with research items demonstrating the mutation of the market as well as the need of professionals who are prepared to meet international challenges. For this, skills and abilities are the subject of analysis of the professionals who will take on knowledge management. The responsibility of the institution of higher education is to demonstrate what the paths are for developing skills, presenting the international scenario as a goal to be attained for career growth, in other words, theory and practice need to walk side by side.

The interviewees also pointed out that internationalization practices of companies and businesses involve long-term commitments, especially when it comes to economic, financial, and human resources. Under the latter, it is considered to be the most important, since they involve behavior and situations that are not always well defined or having accurate metrics, depending a lot on the perception and sensibility of the collaborators and human talents involved. Knowledge management, as well as intellectual capital, becomes the greatest challenge for all those who seek sustainability and success in international business.

\section{References}

Adizes, I. (2004). Gerenciando os ciclos de vida das organizações. São Paulo: Prentice-Hall.

Alavi, M., \& Leidner, D. E. (2001). Review: Knowledge management and knowledge management systems: Conceptual foundations and research issues. MIS Quarterly, 25(1), 107-136.

Albrecht, K (2006). Inteligência social: A nova ciência do sucesso. São Paulo: M. Books.

Cavusgil, S. T., Knight, G., \& Risenberger, J. R. (2010). Negócios internacionais: Estratégia, gestão e novas realidades. São Paulo: Pearson.

Chiavenato, I. (2009). Recursos humanos: O capital humano das organizações ( $9^{\mathrm{a}}$ ed.). São Paulo: Elsevier Campus.

Daniels, J. L., \& Daniel, N. C. (1996). Visão global: Criando novos modelos para as empresas do futuro. São Paulo: Makron. 136.

Dicken, P. (2010). Mudança global: Mapeando as novas fronteiras da economia mundial (5 ed.). Porto Alegre: Bookman.

Dutra, J. S. (2004). Gestão de pessoas: Modelo, processos, tendências e perspectivas. São Paulo: Atlas.

Fernandes, B. R. (2013). Gestão estratégica de pessoas com foco em competências. Rio de Janeiro: Elsevier.19;48.

Fleury, A. C. C., \& Fleury, M. T. L. (2004). Estratégias empresariais e formação de competências: Um quebracabeça caleidoscópico da indústria brasileira (3rd ed.). São Paulo: Atlas.

Gramigna, M. R. (2007). Modelo de competências e gestão dos talentos (2 $2^{\mathrm{a}}$ ed.). São Paulo: Prentice-Hall.

Hengemuhle, A. (2014). Desafios educacionais na formação de empreendedores. Porto Alegre: Penso.

Kuazaqui, E. (2007). Marketing internacional: Desenvolvendo conhecimentos e competências em cenários globais. São Paulo: M. Books. 
Limongi-França, A. C. (2005). Stress e trabalho (4th ed.). São Paulo: Atlas.

Lisboa, T. C. (2016). Competências de gestores no processo de humanização. São Paulo: Laços.

Lowman, J. (2004). Dominando as técnicas de ensino (2 ed.). São Paulo: Atlas.

Meireles, M., \& Paixão, M. R. (2003). Teorias da administração: Clássicas e modernas. São Paulo: Futura.

Morin, E. (2008). O método 1: A natureza da natureza (2 ${ }^{\mathrm{a}}$ ed.). Porto Alegre: Sulina.

Pfeil, O. P. (2003). The valuation of intellectual capital: Massachusetts Institute of Technology. Retrieved May 22, 2018, from http://papers.ssrn.com/sol3/papers.cfm?abstract_id=388100

Queiroz, C. (2008). As competências das pessoas: potencializando seus talentos (6 ${ }^{\mathrm{a}}$ ed.). São Paulo: DVS Editora.

Ribeiro, A. L. (2012). Gestão de pessoas (2nd ed.). São Paulo: Saraiva.

Takeuchi, H., \& Nonaka, I. (2009). Gestão do conhecimento. Porto Algre: Bookman.

Vergara, S. C. (2014). Projetos e relatórios de pesquisa em administração (15ª ed.). São Paulo: Atlas.

Ward, M. (1998). Técnicas essenciais da administração. São Paulo: Nobel. 